Unfortunately, our survey shows that most trainees who would like to engage with research have not had access. There is currently a unique opportunity to build upon the recent surge in research interest following widespread engagement in COVID-19 trials. There is a lack of accessible research experience for respiratory trainees. A potential solution would be a national trainee research network which could provide a unique opportunity for the creation of high-quality collaborative research spearheaded by trainees.

\section{P174 RESEARCH FOR ALL: THE IMPACT OF NWCORR, A TRAINEE RESEARCH COLLABORATIVE}

1,2V Randles, 2,3P Bradley, 2,3,4 L Pearmain, 2,5F Frost, ${ }^{6,7} \mathrm{~A}$ Ashish. ${ }^{1}$ Department of Respiratory Medicine, Liverpool University Hospitals NHS Foundation Trust, Liverpool, UK; ${ }^{2}$ North West Collaborative Organisation for Respiratory Research (NWCORR), Liverpool/ Manchester, UK; ${ }^{3}$ North West Lung Centre, Wythenshawe Hospital, Manchester University NHS Foundation Trust, Manchester, UK; ${ }^{4}$ Wellcome Trust Centre for Cell-Matrix Research, University of Manchester, Manchester, UK; ${ }^{5}$ Department of Respiratory Medicine, Southport and Ormskirk NHS Trust, Southport, UK; ${ }^{6}$ Respiratory Department, Royal Albert Edward Infirmary, Wrightington, Wigan and Leigh Teaching Hospitals NHS Foundation Trust, Wigan, UK; ${ }^{7}$ NIHR Clinical Research Network Greater Manchester, Manchester, UK

\subsection{6/thorax-2021-BTSabstracts.283}

Introduction and Objectives There is an ongoing need to increase trainees participation in research in order to equip tomorrow's consultants with the skills required to appraise and deliver innovation. Trainee research networks have been established in a range of specialities, resulting in high impact studies benefiting patients whilst involving and developing trainees. However, to date, there are only a few such initiatives in the respiratory community. Here, we describe the experience of a collaborative in the Mersey and North West regions.

Methods Launched in February 2020, the North West Collaborative Organisation for Respiratory Research (NWCORR), has fostered collaboration between respiratory trainees from the Mersey and North West Deaneries to create high quality, multicentre research. This collaborative has been initiated with the support of National Institute of Health Research (NIHR) Clinical Research Network (CRN) Greater Manchester and supported by mentorship from research-active consultants in subspecialties relevant to its projects and Local CRN lead. The network now provides all trainees in clinical training a new pathway to gain valuable experience of research design and delivery through mentorship and networking as valuable part of specialty training.

Results With 42 active members, NWCORR has undertaken three research projects with several projects planned. Over 1300 patients have been included across 13 hospitals, with 39 trainees gaining valuable research experience (see table 1). Trainees have led on all aspects of research projects from design to publication. Completed projects have significantly impacted the care of COVID-19 patients whilst engaging 39 trainees across 2 deaneries and have been published and/or presented to disseminate the results.

Conclusions The experience of NWCORR reflects a high rate of trainee enthusiasm to participate in research alongside clinical training and highlights the potential of collaborative networks. It has enabled trainees who may not wish, or have the opportunity, for an 'out of programme' research post to develop research skills and interests. We believe NWCORR and other trainee research collaboratives can, and should, play a pivotal role in embedding a research culture into everyday practice, improve patient care and build early career researchers within the NHS.

\section{P175 BRONCHOSCOPY TRAINING IN SCOTLAND: FEEDBACK FROM RESPIRATORY TRAINEES DURING THE SARS-COV- 19 PANDEMIC}

K Sharma, F Catterall, J Maclay, J Van Der Horst. Glasgow Royal Infirmary, Glasgow, UK

\subsection{6/thorax-2021-BTSabstracts.284}

Aims and Objectives The curriculum for bronchoscopy training in the UK is generic and lacks clear goals for trainees to achieve. In addition to this, assessment methods currently used are informal and vary according to the individual trainee and trainer. In contrast to this, gastroenterology trainees use the same online platform to log their progress nationwide. The online platform allows trainers to review trainees' progress, thus allowing a focused approach to teaching.

Additionally, the SARS-CoV-19 (COVID-19) pandemic has caused a drastic reduction in bronchoscopy lists, thus curtailing training opportunities. Our aim was to gather feedback on Scottish bronchoscopy training during the COVID-19 pandemic and to identify areas needing improvement more generally.

\begin{tabular}{|c|c|c|c|c|c|c|c|c|}
\hline Study name & Description & Project start & Project end & $\begin{array}{l}\text { No. of trainees } \\
\text { involved }\end{array}$ & $\begin{array}{l}\text { No. of } \\
\text { hospitals }\end{array}$ & $\begin{array}{l}\text { No. of } \\
\text { patients }\end{array}$ & Presentations & Publications \\
\hline CURB-COVID-NOW Project & $\begin{array}{l}\text { Investigating the use of CURB65 } \\
\text { as a prognostic score for COVID- } \\
19 \text { patients. }\end{array}$ & March 2020 & $\begin{array}{l}\text { December } \\
2020\end{array}$ & 19 Trainees & 9 sites & 830 Patients & $\begin{array}{l}\text { BTS Winter } \\
\text { Meeting Feb } 2021\end{array}$ & $\begin{array}{l}\text { BMJ Open Research } \\
\text { DOI: } 10.1136 / \text { bmjresp- } \\
\text { 2020-000729 } \\
\text { PMID: } 33293361 \text { * }\end{array}$ \\
\hline CPAP COVID Project & $\begin{array}{l}\text { Investigating ward-based oxygen } \\
\text { therapy and CPAP in patients } \\
\text { with COVID-19 pneumonitis }\end{array}$ & August 2020 & May 2021 & 18 trainees & 7 Sites & 479 Patients & $\begin{array}{l}\text { North West } \\
\text { Thoracic Society } \\
\text { March } 2021\end{array}$ & $\begin{array}{l}\text { Manuscript in } \\
\text { preparation }\end{array}$ \\
\hline $\begin{array}{l}\text { Post inflation } \\
\text { pneumothorax chest drain } \\
\text { management project }\end{array}$ & $\begin{array}{l}\text { Investigating clamping of chest } \\
\text { drain post pneumothorax } \\
\text { resolution }\end{array}$ & August 2020 & Ongoing & 7 trainees & 4 sites & Ongoing & & \\
\hline
\end{tabular}

* Bradley P, Frost F, Tharmaratnam K, Wootton DG; NW Collaborative Organisation for Respiratory Research. Utility of established prognostic scores in CoVID-19 hospital admissions: multicentre prospective evaluation of CURB-65, NEWS2 and qSOFA. BMJ Open Respir Res. 2020 Dec;7(1):e000729. doi: 10.1136/bmjresp-2020-000729. PMID: 33293361; PMCID: PMC7722817. 